\title{
'n Tydige en omvattende boek oor die emosies van Jesus Christus
}

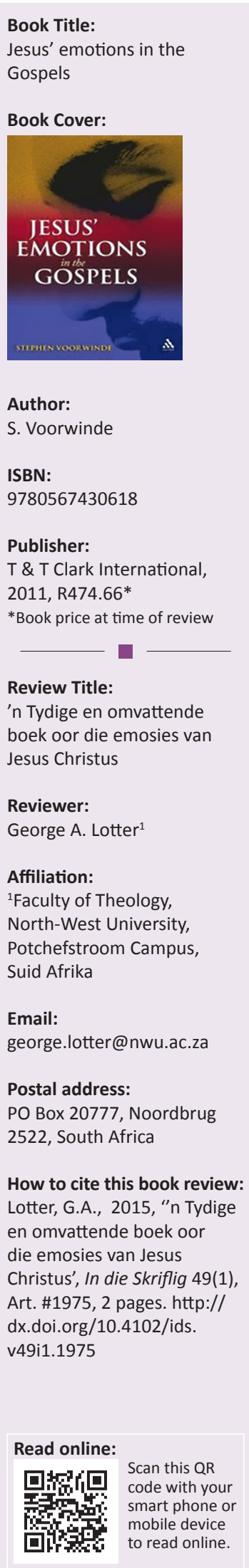

Hierdie publikasie van Stephen Voorwinde, 'n dosent in Nuwe Testament aan die Reformed Theological College, Geelong in Victoria, Australië, is nie 'n ligte lekkerlees boek vir vermaak of bolangse geloofsversterking nie. Dit is 'n goed nagevorste werk wat intense konsentrasie verg om te lees en die inhoud te begryp. Daarom is dit beter om dit stuksgewys te lees of te bestudeer en dit dalk later selfs te herlees om 'n omvattende begrip van die inhoud te kry.

In die inleiding word 'n beskrywing van Jesus se emosies in die verskillende evangelies gegee. Die skrywer dui selfs aan hoeveel keer Jesus se emosies in die evangelies ter sprake is: 28 keer in die Evangelie van Johannes; 16 keer in Markus, 10 keer in Matteus en net 6 keer in Lukas - dus word daar in totaal 60 keer daarna verwys. Voorwinde meen self dis min in vergelyking met die ander aspekte wat in die evangelies beskryf word, soos byvoorbeeld Jesus se wonderwerke, sy gelykenisse en hoe Hy met mense omgegaan het.

Daarna volg die spesifieke fokus op Jesus Christus se afsonderlike emosies (elke evangelie vorm 'n aparte hoofstuk):

Die 'Koning met mededoë' en Jesus se emosies (Matteus).

Die 'Man van Smarte' en Jesus se emosies (Markus).

Die 'Simpatieke Seun' en Jesus se emosies (Lukas).

Die 'Liefdevolle Here' en Jesus se emosies (Johannes).

Die fokuspunt van Jesus se emosies, naamlik sy betrokkenheid by die verbond, of, anders gestel, sy verhouding (kontinuïteit) met die Ou Testament, word in die Evangelie van Matteus gevind. Die Here Jesus Christus vervul die verbond ten koste van Homself en sy eie lewe. Die benaming van Jesus (Joshua) as Verlosser en Christus (Gesalfde), asook die verwysing na die Seun van Dawid (bl. 12 \& 13), onderstreep die Ou-Testamentiese verbintenis. Die emosie wat eerste in Matteus bespreek word, is dié van verwondering oor die geloof van 'n heiden (Matt 8:10) - 'n emosie wat eintlik vreemd is by Iemand wat self God is en alles weet. Dit gaan in Matteus egter meestal oor Jesus se emosies van mededoë met die verskillende skares soos beskryf in 9:35-38, 14:13-21 en 15:29-39, sowel as sy mededoë met die twee blinde mans (Matt 20:29-34).

Geen ander evangelie kyk so diep in die psige van Jesus Christus as Markus nie en die psigologiese dimensie van hierdie evangelieskrywer is iets besonders (bl. 59). Daar word in hierdie evangelie 'n groot verskeidenheid emosies beskryf. Wat hier veral opvallend is, is die beskrywing van twee skynbaar teenstrydige emosies, naamlik mededoë en 'n ernstige waarskuwing (Mark 1:40-45). In Markus 3:5 word hierdie verskynsel soos volg beskryf: 'Terwyl hulle so rondom Hom staan, het Hy hulle die een na die ander verontwaardig aangekyk, diep bedroef oor die gevoelloosheid van hulle harte.' Die emosies van mededoë soos in Matteus beskryf, kom ook in Markus na vore: Jesus se besondere mededoë met die seun wat epileptiese aanvalle gekry het (Mark 9:14-29 veral vers 22). Wat hierdie verhaal uniek maak, is dat die genesing op versoek van die kind se vader plaasgevind het. Markus is ook die enigste evangelis wat Jesus se verontwaardiging teenoor sy dissipels beskryf (Mark 10:14) toe hulle die kindertjies van Hom af wou weghou.

Alhoewel Lukas die langste evangelie is, verwys dit die minste na Jesus se emosies, waarskynlik omdat Lukas nie self 'n ooggetuie was nie, maar sy bevindinge op grond van noukeurige navorsing neergeskryf het (bl. 119). Ten spyte daarvan, word 'n rykdom van intense emosies wat die Here Jesus Christus beleef het beskryf, byvoorbeeld verwondering (bl. 123); mededoë (bl. 125); blydskap (bl. 128); benoudheid (bl. 132); hartseer (bl. 137) en doodsangs (bl. 143). Voorwinde gee 'n besondere beskrywing van Jesus Christus se lyding en hoe Lukas die emosies daaromtrent weergee (bl. 143-148). Hy vat dit soos volg saam: 'Jesus' emotions in Luke form a finely woven tapestry of his humanity, royalty and divinity' (p. 148). 
Johannes is die evangelis wat Jesus se liefde verreweg die meeste beskryf. Van die 28 emosies wat in hierdie evangelie beskryf word, gaan 18 daarvan oor die liefde.

Hierdie liefde word onder andere teenoor die volgende persone uitgedruk:

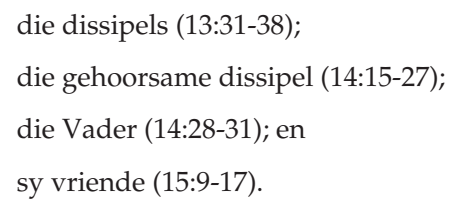

Voordewind beklemtoon dat Jesus se emosies, soos beskryf in Johannes, ' $n$ baie sterk Goddelike sowel as menslike dimensie bevat (bl. 211). Hy sluit af met die volgende stelling:

In taking time to reflect on what motivates Jesus' emotions, we see they can only be seldom be explained in human terms. As one who is aware of both his cosmic origins and divine destiny, Jesus experiences emotions that are extraordinary, paradoxical and at time mysterious and imcoprehensible. Often they lie beyond the realm of normal experience. (p. 213)

Alhoewel die onderwerp van Jesus Christus se emosies homileties, liturgies, pastoraal, akademies en op ander vlakke aandag ontvang, is navorsing steeds te min vir so 'n belangrike aspek. Dit gaan immers oor die persoon wat die wêreldgeskiedenis onherroeplik verander het, of, sterker gestel, die enigste ware Redder van die wêreld. Die studie van Voorwinde is daarom tydig en besonder volledig sover dit die eksegese, sosiohistoriese agtergrond en hermeneutiese toepassing aangaan.

Dit word sterk vir alle teologiese studente, predikante en Nuwe Testamentiese navorsers aanbeveel! 